\title{
Impact of activated sludge bulking and foaming on the quality of Kuwait's irrigation water
}

\author{
Abdallah Abusam ${ }^{1, *}$, Andrzej Mydlarczyk ${ }^{2}$, Fadila Al-Salamain ${ }^{3}$, and Moh Ahmed ${ }^{4}$ \\ ${ }^{1,2,4}$ WRC, WTRT Program, Kuwait Institute for Scientific Research, Kuwait \\ ${ }^{3}$ ELSRC, Biotechnology Program, Kuwait Institute for Scientific Research, Kuwait
}

\begin{abstract}
Treated municipal wastewater produced in Kuwait is used mainly in agricultural and landscape irrigations. However, there are strong doubts that severe sludge bulking and foaming problems, particularly during winter seasons, may render this water unsuitable for irrigation purposes. To assess the impact of these problems on the quality of irrigation water in Kuwait, samples of secondary and tertiary effluents and sludge-mixed liquor were collected weekly from two wastewater treatment plants for nine months. Routine wastewater quality parameters were then determined for the collected influent and effluent samples. Further, dominant filamentous bacteria in the sludge-mixed liquor samples collected from the aeration tanks were also identified and quantified using a molecular method called Vermicon Identification Technology (VIT). Obtained results of the effluents' qualities were then statistically analyzed and compared to Kuwait's irrigation water standards. Statistical results indicated that secondary effluents were greatly impacted by sludge bulking and foaming problems, while tertiary effluents were slightly affected. This finding highlights the importance of having tertiary treatment units in plants to encounter sludge bulking and foaming problems.
\end{abstract}

\section{Introduction}

Kuwait has no natural freshwater resource other than scarce amounts of brackish groundwater, which is overexploited. Due to the scarcity of natural freshwater resources, Kuwait has depended, for a long time, on the expensive processes of seawater desalination to satisfy almost all of its water demands. To maintain sustainable development and lifestyle, the country has recently adopted a vigorous campaign to use treated municipal wastewater, mainly in agricultural and landscape irrigations [1].

Kuwait treats its municipal wastewater at four main activated sludge plants, located in Kabd, Riqqa, Sulaibiya and Umm Al-Haiman. Except for the Sulaibiya plant, all of these plants encounter severe, filamentous sludge bulking and foaming problems, particularly during the winter season. Sludge bulking and foaming usually results in poor effluent quality, odor nuisances and sludge management problems [2]-[5]. If not controlled properly, the excessive sludge bulking and foaming can lead to many operational problems and even to a complete failure of the entire wastewater treatment process [6]. Filamentous microorganisms constitute a natural part of the microorganisms of the activated sludge systems [7]. It provides a backbone to the floc [8]. However, the imbalance between the floc-forming and filamentous microorganisms often results in bulking and foaming problems. Various types of filamentous bacteria are implicated in developing sludge bulking and foaming problems. This study assesses the impacts of filamentous bulking and foaming on two activated sludge wastewater treatment plants (WWTPs) in Kuwait, through analysing samples collected from the secondary and tertiary effluents and sludge-mixed liquor of two wastewater treatment plants.

\section{Materials and methods}

\subsection{Plant's Description}

The plants studied were Riqqa and Umm Al-Haiman WWTPs. Both of these are activated sludge plants, which treat mainly medium strength domestic wastewater up to a tertiary level, using sand filtration and chlorine disinfection. The design capacity of Riqqa WWTP is $185,000 \mathrm{~m}^{3} / \mathrm{d}$, whereas that of Umm-Al-Haiman WWTP is $27,000 \mathrm{~m}^{3} / \mathrm{d}$.

\subsection{Sample Collection and handling}

$1000 \mathrm{ml}$ grab samples of wastewater and sludge were collected weekly during the period from January to August 2014. In Kuwait, the weather from January to April is winter, while from May to August is summer. Wastewater and sludge samples were collected in sterile bottles from the aeration tank and the influent, secondary effluent and tertiary effluent streams. After the insitu measurement of temperature (Temp), electrical conductivity (EC) and hydrogen ion concentrations $(\mathrm{pH})$,

* Corresponding author: aabusam@kisr.edu.kw 
the samples were placed in an icebox and immediately transported to the laboratories of Sulaibiya Research Plant (SRP) of the Kuwait Institute for Scientific Research (KISR) for analyzing the routine quality parameters of wastewater, such as total suspended solids (TSS), five-days biochemical oxygen demand (BOD5), chemical oxygen demand (COD), ammonium nitrogen (NH4-N), nitrate nitrogen (NO3-N) and total phosphorus (TP), which were determined according to standard methods [9].

\subsection{Filament Identification and Quantification}

Filamentous bacteria were identified and quantified using the Vermicon Identification Technology, which is based on molecular biology principles. The following VIT kits were purchased from Vermicon Inc., Munich, Germany: VIT-1851, VIT- H. hydrossis, VIT-Nocardiaform, VIT$021 \mathrm{~N} /$ Thiothrix, VIT-N. Limicola II and VIT-M. parvicella. The identification and quantification of the dominant filaments were carried out according to the manufacturer's instructions. The abundance of the identified filaments was then quantified using the VIT proposed scoring scale, which ranges from zero to five $(0$ : None; 1: few; 2: some; 3: many; 4: abundant; and 5: excessive). Notice that identification and quantification processes of filamentous bacteria were limited to only the types for which VIT kits has been purchased.

\section{Results and discussion}

Figs. 1 and 2 present the VIT scores of the six filamentous bacteria found in the samples collected from the aeration tank of Riqqa plant. These figures show that the identified filaments started from almost none (scale 0 ) or few (scale 1) level in the first half of January and rapidly became abundant (scale 4) or even excessive (scale 5) in only a few weeks. These figures show that the concentrations of the filaments were fluctuating over time. Fig. 1 shows that the concentrations of Microthrix and Nocardioform have the highest rate of fluctuations over time. Surprisingly, it appears as if there is no apparent seasonal shift in the population of the filaments, except for the abrupt drop in the scores of Microthrix and Nocardioform during the warmest month of June-August.

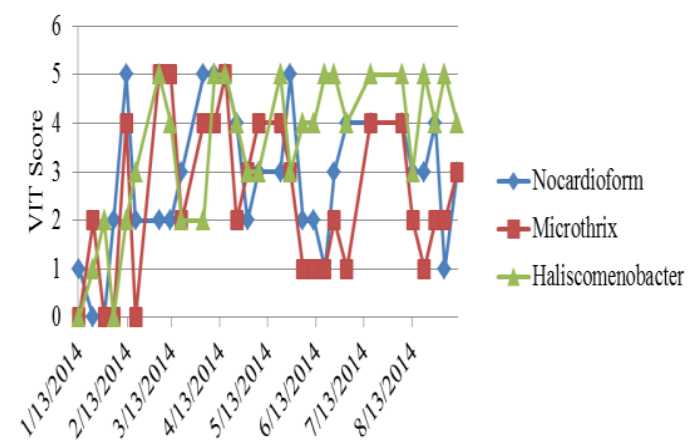

Fig. 1. Scores of Nocardiaform, Microthrix and Haliscomenbacter in samples collected from Riqqa aeration tank

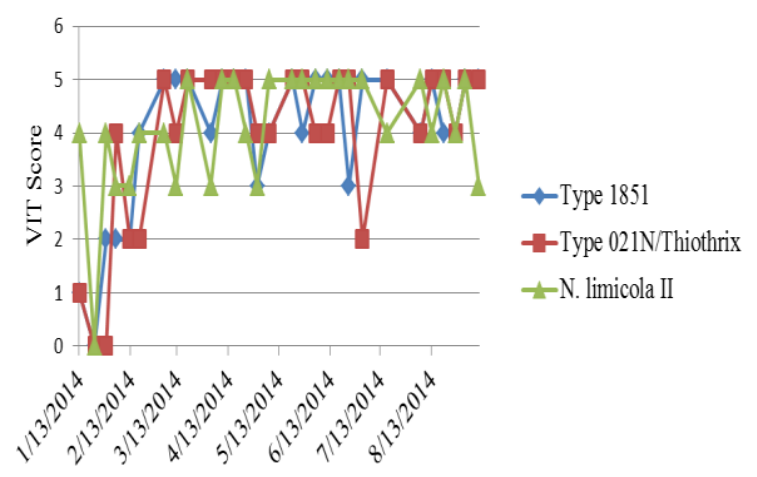

Fig. 2. Scores of Type 1851, Type 021N/Thiothrix and N. limicola in samples collected from Riqqa aeration tank

Figs. 3 and 4 show that filamentous bacteria identified in the samples collected from the aeration tank of Umm Al-Haiman plant have the same rapid trend of growth and almost the same flocculation in population dynamics. Similar to Riqqa plant, Microthrix and Nocardioform are shown to have the highest dynamics and significant drop in population due to a sharp increase in water temperature during the period from June to August. Although the growth of the identified filaments is clearly triggered by the sharp drop in water temperature at the beginning of the winter season (December-January), the sharp increase in temperature during summer seemed to have an effect only on Microthrix and Nocardioform. Such seasonal shift in the population of filaments was also observed by [10].

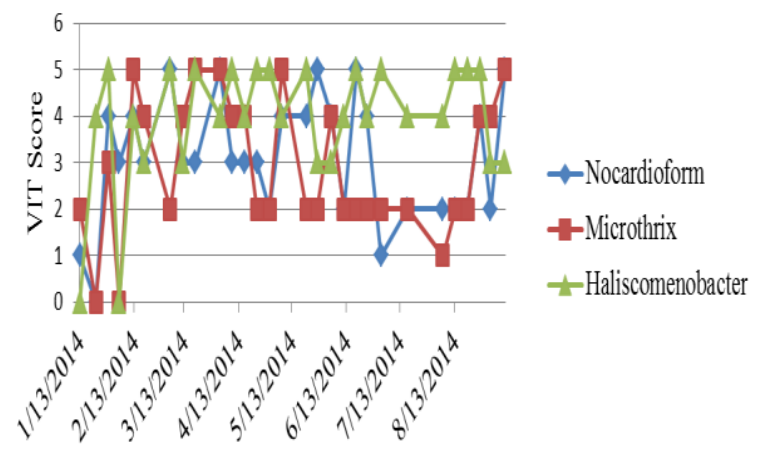

Fig. 3. Scores of Nocardioform, Microthrix and Haliscomenbacter in samples collected from the aeration tank of Umm Al-Haiman plant

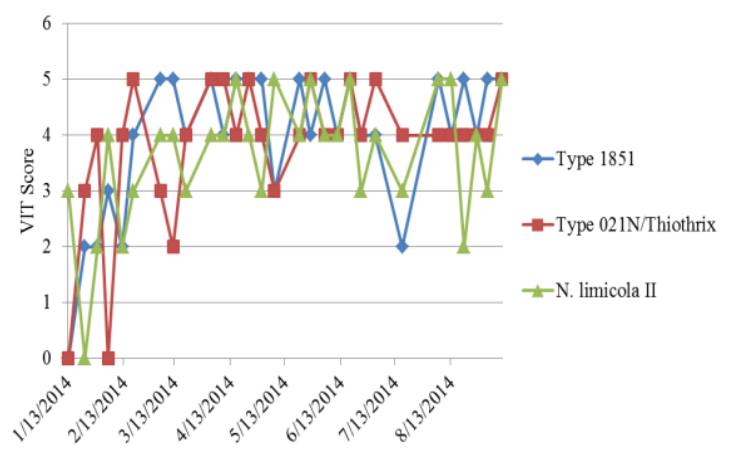

Fig. 4. Scores of Type 1851, Type 021N/Thiothrix and N. limicolla in samples collected from the aeration tank of Umm Al-Haiman plant 
The qualities of the secondary effluents of Riqqa plant and Umm Al-Haiman plant are given in Tables I and II, respectively. Table 1 shows that the secondary effluent of the Riqqa system was significantly poorer in quality during the winter season than in the summer season. Actually, the concentrations of solids, organics and nonorganics (e.g., nitrogen and phosphorus) during winter were almost double or even triple compared to those during summer. That is, the impact of the proliferation of filamentous bacteria was very apparent in the secondary effluent of Riqqa WWTP during the winter season. Such an impact, however, was not found for Umm Al-Haiman's secondary effluent (Table II), as the concentrations of solids, organics and nonorganics (e.g., nitrogen and phosphorus) in the secondary effluents of Umm Al-Haiman WWTP during winter were almost the same as those during summer.

Table 1. Quality of Riqqa secondary effluent

\begin{tabular}{|c|c|c|c|c|}
\hline & \multicolumn{2}{|c|}{ Winter Period } & \multicolumn{2}{c|}{ Summer Period } \\
\hline & Mean & $\begin{array}{c}\text { Standard } \\
\text { Deviation }\end{array}$ & Mean & $\begin{array}{c}\text { Standard } \\
\text { Deviation }\end{array}$ \\
\hline TSS & 81.70 & 49.16 & 39.16 & 36.66 \\
\hline COD & 154.10 & 118.39 & 66.12 & 62.60 \\
\hline BOD5 & 70.72 & 48.38 & 32.18 & 34.82 \\
\hline TN & 19.14 & 12.04 & 8.88 & 3.14 \\
\hline NH4-N & 9.38 & 5.63 & 3.16 & 4.40 \\
\hline NO3-N & 4.92 & 4.04 & 5.45 & 3.17 \\
\hline TP & 1.42 & 0.42 & 1.09 & 0.34 \\
\hline
\end{tabular}

Table 2. Quality of Umm Al-Haiman secondary effluent

\begin{tabular}{|c|c|c|c|c|}
\hline & \multicolumn{2}{|c|}{ Winter Period } & \multicolumn{2}{c|}{ Summer Period } \\
\hline & Mean & $\begin{array}{c}\text { Standard } \\
\text { Deviation }\end{array}$ & Mean & $\begin{array}{c}\text { Standard } \\
\text { Deviation }\end{array}$ \\
\hline TSS & 2.47 & 0.73 & 3.68 & 2.43 \\
\hline COD & 10.67 & 5 & 10.74 & 4.42 \\
\hline BOD5 & 3.19 & 1 & 2.91 & 2.46 \\
\hline TN & 5.16 & 3.74 & 6.66 & 2.75 \\
\hline NH4-N & 0.04 & 0.1 & 0.59 & 1.36 \\
\hline NO3-N & 4.66 & 3.18 & 5.75 & 2.78 \\
\hline TP & 0.99 & 0.43 & 1.23 & 0.23 \\
\hline
\end{tabular}

With respect to the tertiary effluents, there is an apparent impact of sludge bulking and foaming on the tertiary effluents of Riqqa plant during the winter season (Table III). However, the magnitude of this impact is not as huge as that on the secondary effluents. This was probably due to the tertiary treatment units (sand filters and chlorination units) used in the plant. For Umm AlHaiman plant, however, the tertiary effluents were not significantly affected by the filamentous bulking during the winter season as shown in Table IV.

Table 3. Quality of Riqqa tertiary effluent

\begin{tabular}{|c|c|c|c|c|}
\hline & \multicolumn{2}{|c|}{ Winter Period } & \multicolumn{2}{c|}{ Summer Period } \\
\hline & Mean & $\begin{array}{c}\text { Standard } \\
\text { Deviation }\end{array}$ & Mean & $\begin{array}{c}\text { Standard } \\
\text { Deviation }\end{array}$ \\
\hline TSS & 57.11 & 36.99 & 27.87 & 30.06 \\
\hline COD & 94.75 & 53.94 & 48.14 & 46.69 \\
\hline BOD5 & 47.02 & 31.27 & 24.19 & 29.07 \\
\hline TN & 17.06 & 12.27 & 7.37 & 2.75 \\
\hline NH4-N & 8.77 & 5.37 & 1.69 & 2.01 \\
\hline
\end{tabular}

\begin{tabular}{|c|c|c|c|c|}
\hline NO3-N & 2.89 & 2.7 & 5.61 & 3.8 \\
\hline TP & 1.46 & 1.06 & 0.91 & 0.32 \\
\hline
\end{tabular}

Table 4. Quality of Umm Al-Haiman tertiary effluent

\begin{tabular}{|c|c|c|c|c|}
\hline & \multicolumn{2}{|c|}{ Winter Period } & \multicolumn{2}{c|}{ Summer Period } \\
\hline & Mean & $\begin{array}{c}\text { Standard } \\
\text { Deviation }\end{array}$ & Mean & $\begin{array}{c}\text { Standard } \\
\text { Deviation }\end{array}$ \\
\hline TSS & 1.59 & 0.52 & 1.79 & 1.15 \\
\hline COD & 7.89 & 3.42 & 7.54 & 2.67 \\
\hline BOD5 & 4.19 & 6.76 & 1.57 & 1.74 \\
\hline TN & 4.54 & 3.58 & 6.64 & 2.25 \\
\hline NH4-N & 0.01 & 0.03 & 0.45 & 0.97 \\
\hline NO3-N & 4.35 & 3.42 & 6.27 & 2.52 \\
\hline TP & 0.96 & 0.16 & 0.99 & 0.3 \\
\hline
\end{tabular}

As shown above, both of the secondary and the tertiary effluents of Umm Al-Haiman plant were not significantly affected by the filamentous bacteria dominating the system, while the effluents of Riqqa plant were greatly affected. In an attempt to explain these phenomena, the control variables of activated sludge systems were estimated and compared (Tables V and VI). The following control variables were estimated: mixed liquor suspended solids (MLSS), aeration tank dissolved oxygen $\left(\mathrm{DO}_{\mathrm{AT}}\right)$, hydraulic retention time (HRT), organic loading (OL) and food-to-microorganisms (F/M) ratio. Table V compares the operational variables of Riqqaactivated sludge system in the winter season to that in those summer season. It shows that the system was operated at a very low DO concentration throughout the year (below $0.3 \mathrm{mg} / \mathrm{l}$ ). It also shows that the $\mathrm{F} / \mathrm{M}$ ratio was relatively high due to high OL and low MLSS, particularly during the winter season. In contrast, Table 6 shows that Umm Al-Haiman's system was operated at a relatively higher DO and lower F/M ratio. But surprisingly, the same table also shows that this system was operated at a very high MLSS concentration during both winter and summer seasons $(7566 \mathrm{mg} / 1$ and 7379 $\mathrm{mg} / \mathrm{l}$, respectively). Probably, the management of this plant wanted to minimize the amount of surplus sludge produced. Although this strategy reduces the adverse impact of filaments' abundance on the performance of the system, it increases the aeration costs and consequently, the overall operational costs of the plant.

Table 5. Operational data of Umm Al-Haiman activated sludge system

\begin{tabular}{|c|c|c|c|c|}
\hline & \multicolumn{2}{|c|}{ Winter Period } & \multicolumn{2}{c|}{ Summer Period } \\
\hline & Mean & $\begin{array}{c}\text { Standard } \\
\text { Deviation }\end{array}$ & Mean & $\begin{array}{c}\text { Standard } \\
\text { Deviation }\end{array}$ \\
\hline MLSS & 2563.5 & 325.6 & 3481.5 & 649.3 \\
\hline DO & 0.13 & 0.07 & 0.29 & 0.06 \\
\hline HRT & 12 & 0.87 & 13.82 & 10.1 \\
\hline OL & 0.66 & 0.19 & 0.57 & 0.4 \\
\hline F/M & 0.26 & 0.09 & 0.17 & 0.16 \\
\hline
\end{tabular}

Table 6. Operational data of Riqqa activated sludge system

\begin{tabular}{|c|c|c|c|c|}
\hline & \multicolumn{2}{|c|}{ Winter Period } & \multicolumn{2}{c|}{ Summer Period } \\
\hline & Mean & $\begin{array}{c}\text { Standard } \\
\text { Deviation }\end{array}$ & Mean & $\begin{array}{c}\text { Standard } \\
\text { Deviation }\end{array}$ \\
\hline MLSS & 7566 & 627 & 7379 & 787 \\
\hline DO & 1.86 & 1.28 & 1.54 & 0.62 \\
\hline
\end{tabular}




\begin{tabular}{|c|c|c|c|c|}
\hline HRT & 34.9 & 4 & 32.8 & 5.1 \\
\hline OL & 0.2 & 0.1 & 0.31 & 0.08 \\
\hline F/M & 0.03 & 0.01 & 0.04 & 0.01 \\
\hline
\end{tabular}

\section{Conclusions}

Filamentous bacteria dominated both Riqqa and UmmAl-Haiman WWTPs.

Riqqa plant was significantly impacted by the excessive growth of filamentous bacteria as the quality of its secondary effluent greatly deteriorated. However, the impact on its tertiary effluent was dampened by the tertiary treatment units (sand filters and chlorination units) used at this plant.

The insignificant impact of filamentous bacteria on the performance of Umm Al-Haiman plant can mainly be attributed to the operation of the activated sludge system at a very high MLSS concentration (above 7,000 mg/l), which was almost three times more than that of the Riqqa plant.

The study was supported by the Kuwait Foundation for the Advancement of Sciences (KFAS) under the Code: 2012-140502 .

\section{References}

1. Al-Shammari, and A. M. Shahalam, Proc. of $7^{\text {th }}$ Water Conference on Water in the GCC - Towards an Integrated Management, WASTA, Kuwait, 701 (2005).

2. MetCalf and Eddy, $4^{\text {rd }}$ ed. New York: McGraw-Hill Publishing Company, Ltd., (2003).

3. P.H. Nielsen, C. Kragelind, R.J. Seviour and J.L. Nielsen, FEMS Microbiol. Rev., 33, 969 (2009).

4. S. Posavac, T.L. Dragicevic, and M.Z. Hren, Mljekarstv,o 60, 198 (2010).

5. 5. Z. Li, T. Zhang, N. Li, and X. Wang, J. Env. Sci., vol. 22, 62 (2010).

6. D. Soltysik, I. Bednarek, S. Galka and D. Sypniewski, Env. Mon. and Assess., 176, 343 (2011).

7. P. Madoni, D. Davoli and G. Gibin, Wat. Res., 34, 1767 (2000).

8. D. Jenkins, M.G. Richard and G.T. Daigger, Lewis Publishers, New York, USA (1993).

9. APHA, Standard Methods for the Examination of Water and Wastewater, 21 ${ }^{\text {st }}$ edition, Baltimore, Maryland, USA: American Public Health Association, (2012)

10. J. Wanner, I. Ruzicková, P. Jetmarová, O. Krhutková and J. Paraniaková, Wat. Sci. and Technol., vol. 37, 271 (1998). 